\title{
Sequencing the Black Aspergilli species complex
}

\author{
Alan Kuo ${ }^{1}$, Asaf Salamov, ${ }^{1}$ Kemin Zhou ${ }^{1,}$ Robert Otillarr, ${ }^{1,}$ cott Baker ${ }^{2}$ and Igor Grigoriev ${ }^{1}$ \\ ${ }^{1}$ DOE Joint Genome Institute and ${ }^{2}$ Pacific Northwest National Lab \\ ${ }^{1}$ To whom correspondence may be addressed. E-mail: akuo@lbl.gov.
}

March 14, 2011

\section{ACKNOWLEDGMENTS:}

The work conducted by the U.S. Department of Energy Joint Genome Institute is supported by the Office of Science of the U.S. Department of Energy under Contract No. DE-AC02$05 \mathrm{CH} 11231$.

\section{DISCLAIMER:}

This document was prepared as an account of work sponsored by the United States Government. While this document is believed to contain correct information, neither the United States Government nor any agency thereof, nor The Regents of the University of California, nor any of their employees, makes any warranty, express or implied, or assumes any legal responsibility for the accuracy, completeness, or usefulness of any information, apparatus, product, or process disclosed, or represents that its use would not infringe privately owned rights. Reference herein to any specific commercial product, process, or service by its trade name, trademark, manufacturer, or otherwise, does not necessarily constitute or imply its endorsement, recommendation, or favoring by the United States Government or any agency thereof, or The Regents of the University of California. The views and opinions of authors expressed herein do not necessarily state or reflect those of the United States Government or any agency thereof or The Regents of the University of California. 


\section{Sequencing the Black Aspergilli species complex}

Kuo, Alan ${ }^{1 *}$, Asaf Salamov ${ }^{1}$, Kemin Zhou ${ }^{1}$, Robert Otillar ${ }^{1}$, Scott Baker ${ }^{2}$, and Igor Grigoriev ${ }^{1}$ ${ }^{1}$ DOE Joint Genome Institute, USA, 2Pacific Northwest National Lab, USA, "akuo@lbl.gov

Abstract

The - 15 members of the Aspergillus section Nigri species complex (the "Black as members of soil microbial communities and players in the global carbon cycle. and as food processing and spoilage agents and agricultural toxigens. Despite complex's members, and thus their taxonoland, is poorly definined. We are using
chart read pyroseguencing technology (Roche rapidly scale up genomic and transcriptomic analysis of this species complex. To

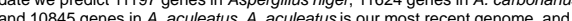
was assembled primarily from 454-sequenced reads and annotated with the deploy these very large numbers of ESTs we developed 2 novel methods for propose orthologies and paralogies among genes in the species complex. In the
near future we will apply these methods to additional species of Black Aspergilli
that are currently in our sequencing pipeline.

The Black Aspergilli (Nigri complex)

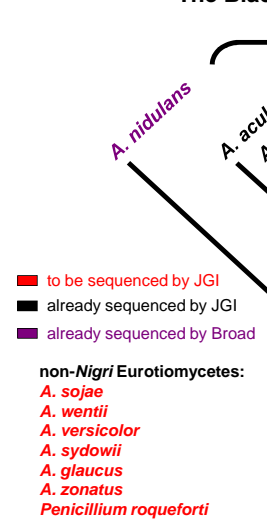

人

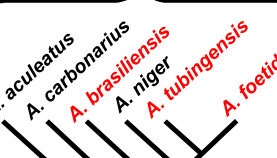

y

A. wojae

A. sydowii
A. glaucus

A. zonatus
Penicillium roquefort

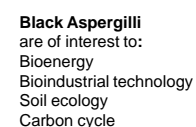

Soll ecology
Carbon cycle
Food pocessing

Food spoilage
Food toxicity already sequenced by JG
already sequenced by Broad

Aspergilli in MycoCosm: Genome statistics

\begin{tabular}{|l|r|r|r|r|}
\hline & aculeatus & carbonarius & niger & $\begin{array}{r}\text { nidulans } \\
\text { (AspGD) }\end{array}$ \\
\hline Assembly size (Mbp) & 35.4 & 36.3 & 34.9 & 30.5 \\
\hline \# of ESTs & 338596947 & 2466582 & 15360 & $\mathrm{NA}$ \\
\hline \# of genes & 10845 & 11624 & 11197 & 10680 \\
\hline w/ alternative transcripts & $6333(58 \%)$ & $\mathrm{ND}$ & $\mathrm{ND}$ & $\mathrm{ND}$ \\
\hline w/ paralogs & $6758(62 \%)$ & $7032(59 \%)$ & $7045(63 \%)$ & $6182(58 \%)$ \\
\hline \# of multigene families & 1561 & 1726 & 1599 & 1961 \\
\hline
\end{tabular}

MycoCosm Eurotiomycetes Node

(http://genome.jgi-psf.org/eurotiomycetes/)

Alternative splicing may affect $A$. aculeatus chloroperoxidase secretion
A. aculeatus locus view

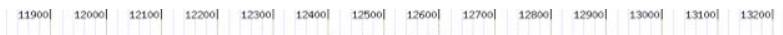

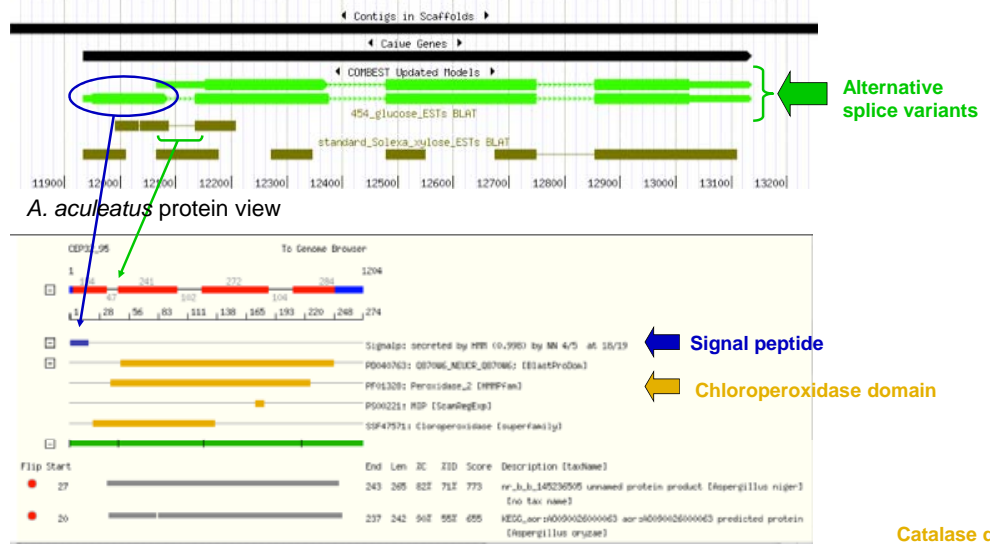

Aspergillus nidulans catalase gene

A. nidulans nrotein va

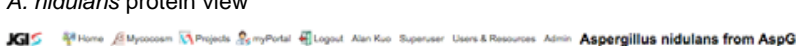

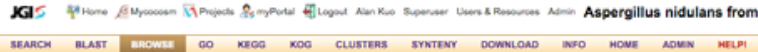

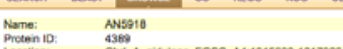

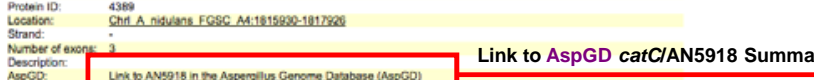

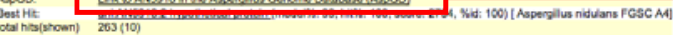

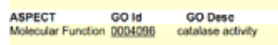

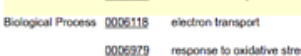

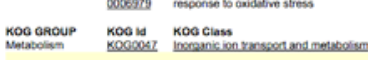

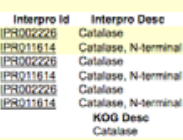

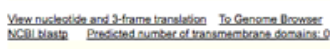

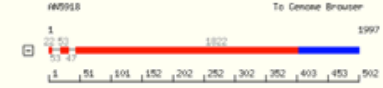

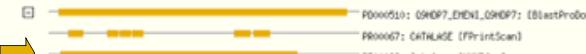

MycoCosm Comparative Genomics View Many Nigri complex gene families are expanded relative to $A$. nidulans Gene families summary view

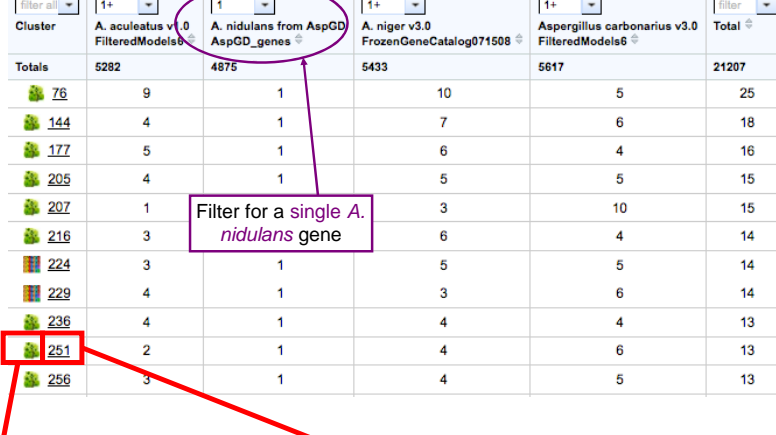

Catalase gene family has multiple duplications and losses

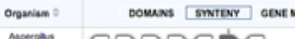

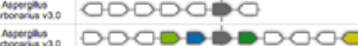

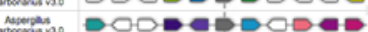
nustor vures 000000000 Nustino 000000000

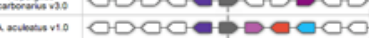
incusurio 0000000000 nnevio 00000000000

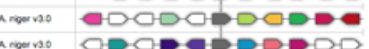
insomion 